Creative Commons User License: CC BY-NC-ND

Abstracted by: EBSCOhost, Electronic Journals Service (EJS),

Google Scholar, Journal Seek, Scientific Commons,

Food and Agricultural Organization (FAO), CABI and Scopus
Journal of Agricultural Extension

Vol. 23 (3) July, 2019

ISSN(e): 24086851; ISSN(Print); 1119944X

http://journal.aesonnigeria.org

http://www.ajol.info/index.php/jae

Email: editorinchief@aesonnigeria.org

\title{
Pre and Post Training Knowledge of Cassava Viral Disease among Farmer and Extension Officer in Nigeria
}

https://dx.doi.org/10.4314/jae.v23i3.5

\author{
Eni, Angela 0.* \\ Department of Biological Sciences, Covenant University, Ogun State Nigeria \\ West African Virus Epidemiology (WAVE) for Root and Tuber Crops, Covenant University, Ogun State Nigeria \\ Email: angela.eni@covenantuniversity.edu.ng +2348063939991
}

\section{Onile-ere, Olabode 0.}

West African Virus Epidemiology (WAVE) for Root and Tuber Crops, Covenant University, Ogun State Nigeria Email: olabode.onile-ere@stu.cu.edu.ng +2347031266812

\section{Mohammed, Ibrahim}

Kebbi State University of Science and Technology, Aliero, (KSUSTA) Kebbi State Nigeria

Email: iumohammed74@gmail.com +2348065680089

\section{Kazeem, Shakiru Adewale}

Nigerian Agricultural Quarantine Services (NAQS), General Research and Biotechnology Unit, Ibadan, Oyo State Email: kazeems2001@gmail.com +2348037760276

\section{Onyeka, Joseph}

National Root Crop Research Institute (NRCRI) of Nigeria, Abia State Nigeria

Email: jonyeka@yahoo.com +2347037067724

\section{*corresponding author}

\section{Abstract}

This study presents findings of a train-the trainer cassava stakeholders training workshop conducted in 2017. Farmers and agricultural extension officers from 12 states and the Federal Capital Territory (FCT) in Nigeria were invited for a 2-day workshop aimed at raising awareness and educating participants on cassava virus disease management. An open-ended questionnaire was used to measure pre and post workshop knowledge alongside practices and needs. A total of 74 persons, 49 farmers and 25 extension officers were included in the study. Participants were mostly males who had been cultivating cassava for $12 \pm 9$ years or had been providing extension services for $17 \pm 9$ years. Pre-workshop knowledge on cassava viral diseases among cassava farmers was poor with farmers scoring an average of $2.04 \pm 1.1$ out of 5 obtainable points on knowledge. Disease management practices were poor among farmers with $40.8 \%$ obtaining planting materials from unverified sources. Post-workshop evaluation showed that farmers' knowledge of cassava viral diseases had increased as adjudged by an average knowledge score of $7.98 \pm 1.80$ out of 11 obtainable points. This study highlights the effectiveness of training in improving farmers' knowledge and equipping them to contribute to the management of cassava viral diseases.

Keywords: extension services; Cassava, training; Cassava mosaic disease (CMD); Cassava brown streak disease (CBSD)

\section{Introduction}

Cassava (Manihot esculenta Crantz) remains a major staple food for over 800 million persons in Africa. It's high calorie content, resilience in many weather conditions and 
Creative Commons User License: CC BY-NC-ND

Abstracted by: EBSCOhost, Electronic Journals Service (EJS), Google Scholar, Journal Seek, Scientific Commons,

Food and Agricultural Organization (FAO), CABI and Scopus
Journal of Agricultural Extension

Vol. 23 (3) July, 2019

ISSN(e): 24086851; ISSN(Print); 1119944X

http://journal.aesonnigeria.org

http://www.ajol.info/index.php/jae

Email: editorinchief@aesonnigeria.org

relatively low cost of production make it suited as a source of nutrition in the mid to low income regions of Africa (Parmar, Sturm, \& Hensel, 2017). Cassava production in Africa is currently threatened by cassava mosaic disease (CMD) and cassava brown streak disease (CBSD) both largely propagated through the exchange of infected planting materials among farmers, and resulting in losses of over 1 billion USD annually (Legg et al., 2015). Currently, CBSD is restricted to East and Central Africa and has not been reported in any West African country. However, reports of the spread of previously localised virulent strains of $\mathrm{CMD}$ to new regions raises concern and necessitates the need for urgent interventions to minimize this trend and ensure continued exclusion of the devastating CBSD from West Africa and/or ensure that the disease is promptly recognized, reported and effectively contained should it be inadvertently introduced into the region. Ongoing efforts to tackle cassava viral disease are mostly directed towards breeding and distribution of virus resistant cassava species with very little documented evidence of farmer education. Farmer education has been shown to improve farmer knowledge, technology adoption and ultimately improve farmer productivity (Paltasingh \& Goyari, 2018). In Nigeria, the responsibility of farmer education falls primarily on agricultural extension services who are often constrained by such factors as funding and the lack of personnel (Hamisu, Ardo, Makinta, Garba, \& Musa, 2017), prompting the need for alternative approaches. This study reports findings of an awareness workshop aimed at training farmers and extension officers on cassava virus disease management.

\section{Methodology}

The study was undertaken during a cassava stakeholder awareness and train-the-trainer workshop conducted by the West African Virus Epidemiology (WAVE) Project in 2017. A 2-day workshop was held in Ota Ogun state $\left(6.6927^{\circ} \mathrm{N}, 3.2365^{\circ} \mathrm{E}\right)$ and sought to train farmers and extension officers on cassava virus diseases with emphasis on the identification and management of CMD which is currently widespread in Nigeria and to create CBSD awareness. At the end of the workshop, it was expected that participants would have acquired enough knowledge to train other farmers and extension officers in their locale.

The study population consisted of farmers and extension officers from 12 Nigerian states and the Federal Capital Territory. Study participants were invited for the workshop through the Nigerian Cassava Growers Association and extension services in south western and north central Nigerian. Participants were incentivised with a stiped to cover the of feeding, accommodation and transportation during the workshop. A total of 74 participants, 51 farmer and 25 extension officers were included in the study; 2 respondents were however dropped from the final analysis due to missing information in their questionnaire.

The workshop was divided into four 1-hour sessions with each session anchored by experts who made power-point presentations and then took feedback from the participants. Sessions were delivered in English language, however participants who did not understand the English language received interpretation from colleagues who did. The themes for the sessions were;

(1) Cassava mosaic disease and cassava brown streak disease identification and control 
Creative Commons User License: CC BY-NC-ND

Abstracted by: EBSCOhost, Electronic Journals Service (EJS), Google Scholar, Journal Seek, Scientific Commons,

Food and Agricultural Organization (FAO), CABI and Scopus
Journal of Agricultural Extension

Vol. 23 (3) July, 2019

ISSN(e): 24086851; ISSN(Print); 1119944X

http://journal.aesonnigeria.org

http://www.ajol.info/index.php/jae

Email: editorinchief@aesonnigeria.org

(2) Clean seed awareness

(3) The role of extension services

(4) The role of quarantine services in ensuring the exclusion of exotic viruses

(5) Status of cassava mosaic disease in Nigeria

At the end of the workshop, participants were given leaflets containing information on the various cassava virus symptoms, important information on transmission and the need for clean seed. Leaflets were made available in English and local languages (Hausa and Yoruba).

Two open-ended questionnaires were used to obtain demographic information, preworkshop knowledge and practices as well as post workshop feedback/learning outcomes. The open-ended approach was adopted to allow respondent express themselves ergo allowing for the identification of issues which may not have been covered in a close ended questionnaire. The questionnaires were divided into five (5) sections corresponding to the different training sessions and filled by respondents before and after every session to account for pre and post session feedback/knowledge. The questionnaire administered to the farmers focused on assessing knowledge and practice while questionnaire administered to the extension officers focused on assessing the role and challenges of extension officers in helping farmers control cassava virus disease.

To analyse responses obtained, a mixed methods content analysis was carried out where codes were derived from previous literature and responses. One researcher read through all the responses to deduce central themes derived by placing similar responses into groups with which a codebook was prepared. Two researchers, using the prepared codebook, independently coded participant responses into excel sheets. Reliability of the codebook was assessed by computing inter-rater agreement of both coders for each question using the kappa statistic. Where kappa was less than $70 \%$, a third researcher examined and adjudged the disparity as required. Final inter-rater reliability for the codebook was computed from the average kappa values of all questions. Average interrater agreement of $\geq 80$ was set as the threshold for proceeding with analysis. Inter-rater agreement was $94.9 \% \pm 0.07$ and $96.14 \% \pm 0.07$ for farmers and extension officer responses, respectively.

\section{Pre-workshop Awareness/Knowledge}

To assess pre-workshop knowledge of farmers about cassava virus disease, an arbitrary scale of awareness was developed. Points were awarded based on how much detail each respondent gave to a particular question. For example, respondents who were able to accurately mention the name or etiological agent of a specific cassava virus disease were assumed to be more aware then a respondent who only mentioned the outcomes of having a cassava virus disease on their farm such as low yield. Scores obtained on this scale were added to scores from correct responses regarding symptom identification and knowledge of clean seed to give a final awareness score. Maximum obtainable score was five (5) while minimum was zero (0). A threshold of 3 points was set for awareness with persons scoring $\geq 3$ rated as having good awareness of cassava virus disease while others were rated as having poor awareness. 
Creative Commons User License: CC BY-NC-ND

Abstracted by: EBSCOhost, Electronic Journals Service (EJS), Google Scholar, Journal Seek, Scientific Commons,

Food and Agricultural Organization (FAO), CABI and Scopus
Journal of Agricultural Extension

Vol. 23 (3) July, 2019

ISSN(e): 24086851; ISSN(Print); 1119944X

http://journal.aesonnigeria.org

http://www.ajol.info/index.php/jae

Email: editorinchief@aesonnigeria.org

To assess pre-workshop knowledge of extension officers, they were asked how they identified virus infected cassava plants. They were scored based on their ability to correctly state common symptoms associated with cassava virus diseases. Symptoms were weighted to adjust for respondents who listed responses that were more definitive of cassava virus disease infection, such as mosaic pattern on leaves, as opposed to nonspecific symptoms such as discolouration of leaves. The perception of extension officers was also assessed by asking them what their view was about cassava virus diseases. Perception was scored based on whether respondent identified cassava virus diseases as a problem and emphasized the need for control.

\section{Post-workshop assessment}

To measure the efficacy of each session, farmers were asked to state two new things they had learnt and two things they would do differently after the workshop. Respondents were awarded points if they correctly stated the key points mentioned during the session. If response was an improvement or correction of a previous wrongly stated notion in the presession evaluation, an extra point was awarded. This scoring rubric was based on the assumption that persons who corrected previously wrong beliefs were more likely to have acquired knowledge experience and as such may be more inclined to take corrective actions in their practices. Total score for post-workshop assessment was aggregated for all sections of the study instrument. Total score obtainable was 11 and 7 was set as the threshold for good post workshop knowledge.

Where necessary, coding was done in binary to accommodate responses that fall into more than one category. Percentage was used to describe distributions, Pearson's correlation was used to examine relationships between continuous variables, while Student's t.test and chi-square were used to compare groups. All statistical analyses were performed in IBM SPSS v25. Kappa statistic was computed using the SciPy 1.0.0 package.

\section{Results and Discussion}

\section{Farmer Participants}

Participants were mostly male (69.4\%), belonged to more than one farmers' association (71.4\%), had been cultivating cassava for an average of 12 years on an average of 11 acres of farmland (Table 1). More than half (54.2\%) of study participants had attended a similar training in the past.

\section{Table 1: Characteristics of farmers}

\begin{tabular}{lrr}
\hline Characteristics & Percentage \% & Mean \pm SD \\
\hline Gender & Female & $30.6 \%$ \\
& $69.4 \%$ & \\
Maltended a training previously & $54.2 \%$ & \\
Belong to more than one farmers' association & $71.4 \%$ & \\
Size of farm & & $11 \pm 14$ \\
Years of practice & & $12 \pm 9$ \\
\hline
\end{tabular}


Creative Commons User License: CC BY-NC-ND

Abstracted by: EBSCOhost, Electronic Journals Service (EJS), Google Scholar, Journal Seek, Scientific Commons,

Food and Agricultural Organization (FAO), CABI and Scopus
Journal of Agricultural Extension

Vol. 23 (3) July, 2019

ISSN(e): 24086851; ISSN(Print); 1119944X

http://journal.aesonnigeria.org

http://www.ajol.info/index.php/jae

Email: editorinchief@aesonnigeria.org

\section{Awareness of Cassava Virus Disease}

Pre-workshop assessment reveals participants had an average knowledge score of $2.04 \pm 1.1$ points out of a maximum obtainable score of 5 (Fig 1$)$. Most farmers $(61.2 \%)$ on seeing pictures of some of the symptoms of cassava virus disease said they recognised the symptoms, however, only $22.4 \%$ of the farmers were able to accurately name a symptom associated with cassava virus disease while $6.1 \%$ accurately named a cassava virus. Farmers who had previously attended trainings were more likely to be aware of cassava virus disease as compared to those who had not. Farm size $(r=0.028)$ and years of practice $(r=-0.187)$ were poorly correlated with awareness.

The poor levels of awareness and weak relationship between awareness, farm size and years of practice found in this study is particularly interesting. This is because most of the farmers included in this study have been cultivating cassava for over 10 years and own medium to large farms based on previously published classifications (Lowder, Skoet, \& Raney, 2016; Ricciardi, Ramankutty, Mehrabi, Jarvis, \& Chookolingo, 2018). One would expect, as is the case of previous studies, that farmers with larger farms would be more likely to invest in staying abreast with recent agricultural information and technologies (Bilaliib, Jincai, Mensah, \& Caesar, 2017; Nakano, Tsusaka, Aida, \& Pede, 2018). This disconnect between level of awareness and years of experience is indicative of poor perceptions of cassava virus diseases as a problem and a preference for traditional methods as opposed to adopting new technologies. The low rates of farmer education (previous attendance of workshop, trainings and extension visits) seen in our study mirrors what is found in other African regions (David, 2013), and the situation may actually be worse. This is because, for most studies, sampling is mostly convenient, covering farmers with farmlands close to cities and excluding those in remote regions which may constitute a larger percentage of farmers (Ricciardi et al., 2018).

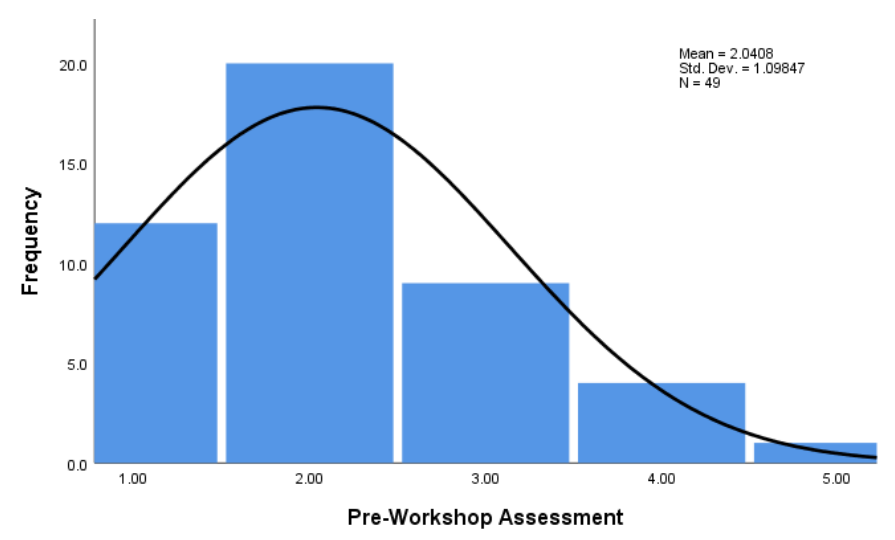

Figure 1: Pre-workshop assessment scores

\section{Cassava Viral Disease Management Practices}

In addition to the poor knowledge of cassava virus diseases, found poor cassava disease management practices was also found among study participants. While phyto-sanitation was the most reported method for preventing disease outbreak, only $46.9 \%$ of respondents reported practising it. Chemical prevention (36.7\%) was the next preferred method of disease prevention as reported by respondents. Sourcing of planting material from neighbouring farms $(40.8 \%)$ or farmers' associations $(30.6 \%)$ was practised by 
Creative Commons User License: CC BY-NC-ND

Abstracted by: EBSCOhost, Electronic Journals Service (EJS), Google Scholar, Journal Seek, Scientific Commons,

Food and Agricultural Organization (FAO), CABI and Scopus
Journal of Agricultural Extension

Vol. 23 (3) July, 2019

ISSN(e): 24086851; ISSN(Print); 1119944X

http://journal.aesonnigeria.org

http://www.ajol.info/index.php/iae

Email: editorinchief@aesonnigeria.org

farmers in our study. This is consistent with a previously reported study (Houngue et al., 2018) and is a major factor promoting the continued spread of cassava virus disease in Africa (Szyniszewska et al., 2017) since these diseases are transmitted through the use of infected planting materials. While none of the farmers had obtained planting materials from outside the country, $23.4 \%$ of them had obtained planting materials from outside their state (Table 2). Of this, most obtained the said planting materials from Ogun state which borders Benin republic. This is especially important as Ogun state is a major transit state through which many foreign food products come into the country.

Table 2: CMD management practice among farmers

\begin{tabular}{lll}
\hline Management practices & & $\begin{array}{l}\text { Percentag } \\
\text { e }\end{array}$ \\
\hline Disease prevention/control & None & $12.2 \%$ \\
& Chemical Prevention & $36.7 \%$ \\
& Rouging & $6.1 \%$ \\
& Virus Free planting & $12.2 \%$ \\
& materials & \\
& Virus Resistant planting & $8.2 \%$ \\
& materials & \\
& Phytosanitation & $46.9 \%$ \\
Where do you obtain & Others & $4.1 \%$ \\
planting materials from? & Neighbouring Farms & $40.8 \%$ \\
& Farmers Association & $30.6 \%$ \\
& Research Institutes & $28.6 \%$ \\
Obtained cassava stems & Extension Officer & $10.2 \%$ \\
from & Previous planting season & $10.2 \%$ \\
& Outside country & $0.0 \%$ \\
& Outside State & $23.4 \%$ \\
\hline
\end{tabular}

\section{Extension Visits}

Almost half $(48.8 \%)$ of the farmers had never been visited by an extension officer in the past 6 months. Farmers who had been visited reported that visits were mostly infrequent. When asked what they would require from extension officers to be more productive, farmers' responses were mostly related to regular visits $(56.1 \%)$ and trainings $(39.0 \%)$. Farmers also stated that they needed the government to help with the provision of inputs $(65.9 \%)$ and finances (39.0\%). It is evident from the results obtained that the agricultural extension agencies may not be able to adequately cater to the stated needs of the farmers hence the need for alternative approaches. Studies from Tanzania (Nakano et al., 2018) and Kenya (Kiptot \& Franzel, 2015) have explored and shown the effectiveness of farmerto-farmer extension services with reports of increased knowledge and yields. Thus, buttressing the need for undertaking this train-the-trainer workshop.

\section{Post Workshop Knowledge}

Post workshop assessment revealed that most participants had improved their knowledge of cassava virus diseases. Farmers had an average assessment score of $7.98 \pm 1.80$ out of 11 obtainable points (Fig 2). There were no significant differences in the assessment scores of persons who had attended trainings in the past and those who had not $(P=0.151)$. Majority of the participants $(79.6 \%)$ had good post assessment scores based on our set threshold. We suspect that the few who did not cross our set threshold for good 
Creative Commons User License: CC BY-NC-ND

Abstracted by: EBSCOhost, Electronic Journals Service (EJS), Google Scholar, Journal Seek, Scientific Commons,

Food and Agricultural Organization (FAO), CABI and Scopus
Journal of Agricultural Extension

Vol. 23 (3) July, 2019

ISSN(e): 24086851; ISSN(Print); 1119944X

http://journal.aesonnigeria.org

http://www.ajol.info/index.php/jae

Email: editorinchief@aesonnigeria.org

post workshop knowledge may have been the non-proficient English speakers. Future training workshops will aim to include translations into local languages to mitigate this problem.

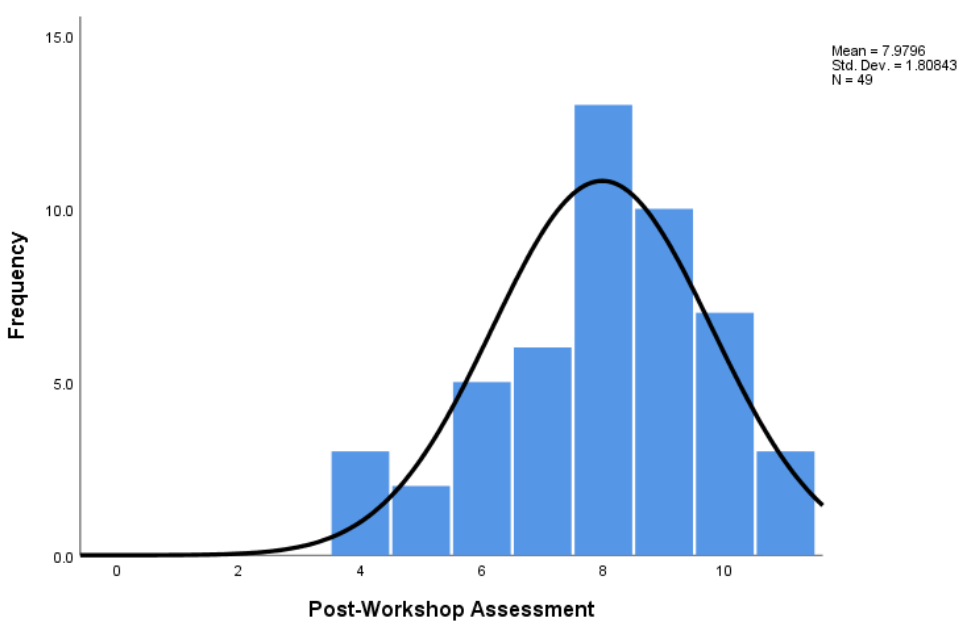

Figure 2: Post-workshop assessment scores

\section{Characteristics of Extension Officers}

Extension officers were mostly male $(80.0 \%)$, had attended trainings in the past $(64.0 \%)$ and had been providing agricultural extension services for an average of $17 \pm 9$ years (Table 3).

\section{Table 3: Characteristics of extension officers}

\begin{tabular}{llrl}
\hline Characteristics of extension officers & Percentage & Mean \pm SD \\
\hline Gender & Female & $20.0 \%$ & \\
& Male & $80.0 \%$ & \\
Previous Trainings & No & $36.0 \%$ & \\
& Yes & $64.0 \%$ & \\
Frequency of training & Regularly & $30.4 \%$ & \\
& Rarely & $69.6 \%$ & $17 \pm 9$ Years \\
Duration of practice & & & (Range 4-29) \\
& &
\end{tabular}

When asked about their view of cassava virus disease, almost all extension officers $(96.0 \%)$ acknowledged cassava virus disease as a problem. However, only $36.0 \%$ emphasized the need for control. To assess knowledge, we asked extension officers how they identified cassava mosaic disease (CMD). The ability of extension officers to identify the disease was poor with only $32 \%$ correctly stating two (2) or more symptoms associated with CMD. Average knowledge score was $1.40 \pm 1.38$ out of an obtainable 7 points. The most commonly mentioned symptoms were yellow colouration (44\%) and distortion (32\%) (Table 4). 
Creative Commons User License: CC BY-NC-ND

Abstracted by: EBSCOhost, Electronic Journals Service (EJS),

Google Scholar, Journal Seek, Scientific Commons,

Food and Agricultural Organization (FAO), CABI and Scopus
Journal of Agricultural Extension

Vol. 23 (3) July, 2019

ISSN(e): 24086851; ISSN(Print); 1119944X

http://journal.aesonnigeria.org

http://www.ajol.info/index.php/jae

Email: editorinchief@aesonnigeria.org

\section{Table 4: Symptom identification by extension officers}

\begin{tabular}{lr}
\hline Symptoms & Percentage Correct \\
\hline Distortion & $32.0 \%$ \\
Mosaic & $0 \%$ \\
Yellow colouration & $44.0 \%$ \\
Whiteflies & $8.0 \%$ \\
Low yield & $32.0 \%$ \\
\hline
\end{tabular}

Extension services provided bordered around training (56.0\%) and the provision of planting materials $(52.0 \%)$ sourced from reputable organisations $(84.0 \%)$ such as the International Institute of Tropical Agriculture (IITA) (52.0\%). With regards to control, physical removal of diseased plants (80\%) and burning $(60 \%)$ were the most recommended practices by extension officers to farmers. Most extension officers (76\%) alluded to having a working partnership with the Nigerian Agricultural Quarantine Services (NAQS) however, responses to subsequent questions about the details of the partnership suggested otherwise. Extension officers cited training, infrastructure, funds and inputs as some of the major needs to better serve farmers.

Although the results obtained here show better knowledge on the part of the extension officers as compared to the farmers, however their ability to identify cassava mosaic disease symptoms was poor. This may stem from the fact that extension officers provide services for a wide variety of crops and as such may not have advanced knowledge of any one crop. This again, underpins the need for complementary extension approaches since it may be impractical to commission crop specific agricultural extension officers. Our results also show the need for more effective partnerships between extension agents and other agricultural agencies to ensure better delivery of extension services.

\section{Conclusion and Recommendations}

There is evidence that farmer training improved farmer knowledge in the management of the spread of cassava viral diseases. There is a need for intensified efforts towards farmer education. Stakeholders should leverage on traditional media sources, such as the radio, especially in local languages, to ensure wider coverage of farmers.

\section{Acknowledgements}

Funding for this work was provided by the Bill and Melinda Gates Foundation and Department for International Development (DFID) Grant no. OPP1082413 "West African Virus Epidemiology (WAVE) for root and tuber crops" through a subgrant from Université Félix Houphouët-Boigny (UFHB).

\section{References}

Bilaliib, U. T., Jincai, Z., Mensah, O. S., \& Caesar, A. E. (2017). Factors Influencing the Agricultural Technology Adoption: The Case of Improved Rice Varieties (Nerica) in the Northern Region, Ghana. Journal of Economics and Sustainable Development, 8(8), 137-148.

David, S. (2013). Learning to Think for Ourselves: Knowledge Improvement and Social Benefits among Farmer Field School Participants in Cameroon. Journal of International Agricultural and Extension Education, 14(2), 35-49. 
Creative Commons User License: CC BY-NC-ND

Abstracted by: EBSCOhost, Electronic Journals Service (EJS), Google Scholar, Journal Seek, Scientific Commons,

Food and Agricultural Organization (FAO), CABI and Scopus
Journal of Agricultural Extension

Vol. 23 (3) July, 2019

ISSN(e): 24086851; ISSN(Print); 1119944X

http://journal.aesonnigeria.org

http://www.ajol.info/index.php/jae

Email: editorinchief@aesonnigeria.org

Hamisu, S., Ardo, A., Makinta, M., Garba, L., \& Musa, G. (2017). A Review on Current Status of Agricultural Extension Service in Nigeria. Asian Journal of Advances in Agricultural Research, 1(3), 1-8.

Houngue, J. A., Pita, J. S., Cacaï, G. H. T., Zandjanakou-Tachin, M., Abidjo, E. A. E., \& Ahanhanzo, C. (2018). Survey of farmers' knowledge of cassava mosaic disease and their preferences for cassava cultivars in three agro-ecological zones in Benin. Journal of Ethnobiology and Ethnomedicine, 14(1), 29.

Kiptot, E., \& Franzel, S. (2015). Farmer-to-farmer extension: opportunities for enhancing performance of volunteer farmer trainers in Kenya. Development in Practice, 25(4), 503-517.

Legg, J., Lava Kumar, P., Makeshkumar, T., Tripathi, L., Ferguson, M., Kanju, E., Ntawuruhunga, P., Cuellar, W. (2015). Cassava Virus Diseases. In Advances in virus research (1st ed., Vol. 91, pp. 85-142).

Lowder, S. K., Skoet, J., \& Raney, T. (2016). The Number, Size, and Distribution of Farms, Smallholder Farms, and Family Farms Worldwide. World Development, 87, 16-29.

Nakano, Y., Tsusaka, T. W., Aida, T., \& Pede, V. O. (2018). Is farmer-to-farmer extension effective? The impact of training on technology adoption and rice farming productivity in Tanzania. World Development, 105, 336-351.

Paltasingh, K. R., \& Goyari, P. (2018). Impact of farmer education on farm productivity under varying technologies: case of paddy growers in India. Agricultural and Food Economics, 6(1), 7.

Parmar, A., Sturm, B., \& Hensel, O. (2017). Crops that feed the world: Production and improvement of cassava for food, feed, and industrial uses. Food Security, 9(5), 907927.

Ricciardi, V., Ramankutty, N., Mehrabi, Z., Jarvis, L., \& Chookolingo, B. (2018). How much of the world's food do smallholders produce? Global Food Security, 17, 64-72.

Szyniszewska, A. M., Busungu, C., Boni, S. B., Shirima, R., Bouwmeester, H., \& Legg, J. P. (2017). Spatial Analysis of Temporal Changes in the Pandemic of Severe Cassava Mosaic Disease in Northwestern Tanzania. Phytopathology, 107(10), 1229-1242. 